14 Liebow A, Steer A, Billingsley J. Desquamative interstitial pneumonia. Am f Med 1965;39:369-404.

15 Carrington C, Gaensler E, Coutu R, Fitzerald M, Gupta R. Natural history and treatment course of usual and desquamative interstitial pneumonia. N Engl f Med 1978;298: 801-9.

16 Turner-Warwick M, Burrows B, Johnson A. Cryptogenic fibrosing alveolitis: response to corticosteroid treatment and its effect on survival. Thorax 1980;35:593-9.

17 Winterbauer RH, Hammer SP, Hallman KO, et al. Diffuse interstitial pneumonitis: clinicopathological correlations in 20 patients treated with prednisolone/azathioprine. $A m \mathcal{F}$ Med 1978;65:661-72.

18 DeRemee RA, Harrison EG, Anderson HA. The concept of classic interstitial pneumonitis-fibrosis (CIP-F) as a clinicopathologic syndrome. Chest 1972;61:213-20.

19 Venn G. Open lung biopsy. Br f Hosp Med 1988;39:272-6.

20 Barnes S, Roberton N. Desquamative fibrosing alveolitis unresponsive to steroid or cytotoxic therapy. Arch Dis Child 1975;50:324-7.
21 Egan J, Woodcock A. Does the treatment of cryptogenic fibrosing alveolitis influence prognosis? Respir Med 1996; 90:127-30

22 Kelly J. Cytokines of the lung. Am Rev Respir Dis 1990;141 $765-88$

23 Lacronique J, Rennard S, Bitterman P, Ozaki T, Crystal R. Alveolar macrophages in idiopathic pulmonary fibrosis have glucocorticoid receptors, but glucocorticoid therapy does not suppress alveolar macrophage release of fibronectin and alveolar macrophage derived growth factor. $A m$ Rev Respir Dis 1984;130:450-6.

24 Kerem E, Bentur L, England S, Resisman J, O'Brodovich K, Bryan A, Levison H. Sequential pulmonary function measurements during treatment of infantile chronic interstitial urements during treatment of infantile

25 Chan-Yeung M, Muller N. Cryptogenic fibrosing alveolitis. Lancet 1997;350:651-6.

26 Bitterman PB, Rennard SJ, Keogh BA, Wewers MD, Adelberg S, Crystal RG. Familial idiopathic pulmonary fibrosis: evidence of lung inflammation in unaffected family members. N Engl F Med 1986;314:1343-7.

\title{
Rapid responses
}

Letters on the following papers have been published recently as rapid responses on the $A D C$ website. To read these letters visit www.archdischild.com and click on "Read rapid responses":

Lung deposition of aerosol: a comparison of different spacers. HJ Zar, EG Weinberg, H J Binns, et al. Arch Dis Child $2000 ; 82: 495-8$.

Paracetamol overdosage. J Whittle, B McGucken. Arch Dis Child 2000;82:428.

Deliberate sulphonylurea poisoning mimicking hyperinsulinaemia of infancy. L Owen, M Ellis, J Shield. Arch Dis Child 2000;82:392-3.

Risk assessment of renal cortical scarring with urinary tract infection by clinical features and ultrasonography. MT Christian, JH McColl, JR MacKenzie, et al. Arch Dis Child 2000;82:376-80.

Anthropometric indices of failure to thrive. P Raynor, MCJ Rudolf. Arch Dis Child 2000;82:364-5.

Sputum induction for the diagnosis of pulmonary tuberculosis in infants and young children in an urban setting in South Africa. H J Zar, E Tannenbaum, P Apolles, et al. Arch Dis Child 2000;82:305-8.

Dipstick examination for urinary tract infections. S Thayyil-Sudhan, S Gupta. Arch Dis Child 2000;82:266.

Effect of prone sleeping on circulatory control in infants. A Chong, N Murphy, T Matthews. Arch Dis Child 2000;82:253-6.

Fits, pyridoxine, and hyperprolinaemia type II. V Walker, GA Mills, SA Peters, et al. Arch Dis Child 2000;82:236-7.

Proteus syndrome and immunodeficiency. D Hodge, SA Misbah, RF Mueller, et al. Arch Dis Child 2000;82:234-5.

Is routine growth monitoring effective? A systematic review of trials. $\mathrm{P}$ Garner, $\mathrm{R}$ Panpanich, $\mathrm{S}$ Logan, et al. Arch Dis Child 2000;82:197-201.

Is the Children Act failing severely abused and neglected children? N Speight, J Wynne. Arch Dis Child 2000;82:192-6.

Guidelines for the ethical conduct of medical research involving children. Royal College of Paediatrics and Child Health: Ethics Advisory Committee and Professor Sir David Hull. Arch Dis Child 2000;82:177-82.

Sedation of children for magnetic resonance imaging. GR Lawson, RJ Bray. Arch Dis Child 2000;82:150-3.

MMR vaccine and allergy. R Lakshman, A Finn. Arch Dis Child 2000;82:93-5.

School based screening for hypothyroidism in Down's syndrome by dried blood spot TSH measurement. SE Noble, K Leyland, CA Findlay, et al. Arch Dis Child 2000;82:27-31.

Dietary products used in infants for treatment and prevention of food allergy. Joint statement of the European Society for Paediatric Allergology and Clinical Immunology (ESPACI) Committee on Hypoallergenic Formulas and the European Society for Paediatric Gastroenterology, Hepatology and Nutrition (ESPGHAN) Committee on Nutrition. A Host, B Koletzko, S Dreborg, et al. Arch Dis Child 1999;81:80-4.

If you would like to post an electronic response to these or any other articles published in the journal, please go to the website, access the article in which you are interested, and click on "eLetters: Submit a reponse to this article" in the box in the top right hand corner. 